\title{
THE USE OF CORRECTIVE TECHNOLOGIES IN THE PROCESS OF PREPARING SENIOR PRESCHOOLERS WITH AUTISM SPECTRUM DISORDER FOR LEARNING ACTIVITIES
}

\author{
Yuliia Sidenko \\ yulia.pochkun@gmail.com \\ Oleksandr Kolyshkin ${ }^{1}$ \\ kolyshkin_av@ukr.net \\ ${ }^{1}$ Department of Special and Inclusive Education \\ Sumy State Pedagogical University named after A. S. Makarenko \\ 87 Romenska str., Sumy, Ukraine, 40002
}

\begin{abstract}
The authors of the article have analyzed scientific research on the problem of the formation of cognitive readiness for educational activity in children with autism spectrum disorders of senior preschool age. It is noted that for children with autism spectrum disorders, a special approach should be applied with a focus on world standards and effective methods of correction and training should be developed. It is revealed that today the psychological and pedagogical correction of the development of autism does not have unambiguity and consistency regarding technologies and methods that would help to effectively overcome autism spectrum disorders and contribute to the effective preparation of autistic children for educational activities. The content of the concept of "cognitive readiness" is revealed as a prerequisite for the development of psychological characteristics and preparation of a child with autism spectrum disorders of senior preschool age for learning activities. The features of the use of correctional technologies to increase the level of cognitive readiness for educational activity of children with autism spectrum disorders of senior preschool age have been determined. It was revealed that the main condition for the formation of cognitive readiness for educational activity in children with autism spectrum disorders of senior preschool age is the use of ABA therapy technology, the TEACCH program, (PRT), PECS, sensory integration. It is revealed that the program (TEACCH, PECS) reflects a clear algorithm of actions, encourages mental operations; method (ABA-therapy) improves the stability of concentration, memory development, forms learning behavior; (PRT) promotes the development of motivation in a child with autism spectrum disorder of senior preschool age, self-management. The formation of imagination and perception of the surrounding world is carried out in the process of conducting classes with sensory integration. It is proved that the formation of cognitive readiness for educational activity in senior preschoolers with autism spectrum disorders is an important factor in the realization of personal potential and social adaptation.
\end{abstract}

Keywords: autism, autism spectrum disorders, senior preschool age, cognitive readiness, correctional technologies.

DOI: $10.21303 / 2504-5571.2020 .001355$

\section{Introduction}

Autism is an extremely complex problem in both theoretical and practical aspects. The current stage of development of the theory and practice of special pedagogy and psychology is characterized by increased attention to in-depth study of the peculiarities of mental development of children with autism spectrum disorders of senior preschool age, cognitive abilities, to identifying the features of the formation of cognitive readiness for educational activities, mental functions, development of the emotional-volitional sphere, social relations, communicative behavior, which is of great scientific and practical importance. The problem of education, upbringing and development of this category of children is rooted in the symptoms of autism. Identifying the early symptoms of autism spectrum disorder allows you to understand the problem and, therefore, provide effective corrective assistance.

The main condition for teaching children with autism spectrum disorders of senior preschool age is student-centered learning, the introduction of innovative educational technologies that provide for a corresponding shift in emphasis in educational activities, and its focus on the 
development of cognitive readiness for educational activities. The educational process today must be oriented towards the personality of a child with autism spectrum disorders and take into account his individual characteristics.

An analysis of modern theoretical and empirical studies and hypotheses on the study of the signs of autism determines the interest in individual deficits in mental activity, that is, cognitive dysfunction, sensory-perceptual characteristics, problematic establishment of social connections, inability to play, the formation of complex emotions in contacts, limitations of working memory, ability to switching attention, auditory perception, abstract thinking, empathy, etc. The concept of studying problems and identifying the signs of autism has been significantly enriched in recent years. This contributes to the development of innovative organizational forms, content, and the use of correction technologies for teaching and upbringing of children with autism spectrum disorders. The problem of the formation of cognitive readiness for educational activities in senior preschool children with autism spectrum disorders by means of correctional technologies in the modern educational space requires a detailed study of the question of how educational technologies can influence the development of cognitive components of children with autism spectrum disorders.

In the Ukrainian correctional psychopedagogy, the problem of the development of children with autism spectrum disorders is actively studied. In particular, Ya. Bagrii, A. Bohdashina studied the essence of autism, but did not determine the methods of early diagnosis of children with autism spectrum disorders [1]. Researcher K. Ostrovska described the problems of psychological assistance to children with autism, but did not reveal the issue of further socialization of children with autism spectrum disorder in the context of modern education [2]. Scientist L. Rybchenko investigated the pedagogical conditions of teaching children with autism spectrum disorders, but theoretically substantiated the pedagogical conditions for organizing correctional work, the practical integration of didactic and correctional means of influencing the development of students with autism spectrum disorders [3]. T. Skrypnyk developed a comprehensive program for the development of children with autism, but did not define the stages of using correction technologies in working with children with autism spectrum disorders of senior preschool age [4]. Researcher V. Tarasun described the concepts of development, learning and socialization of children with autism, but she did not pay enough attention to the integration of prevention and correction of development as a means of solving the problem of preparing a child with autism spectrum disorders to enter society [1]. In her scientific works on autism, G. Khvorova described how to provide psychological and pedagogical assistance to children with autism spectrum disorders, but the study does not sufficiently highlight the issues of organizing the psychological and pedagogical preparation of parents for teaching and upbringing of children with autism spectrum disorders of senior preschool age [5]. D. Shulzhenko investigated the psychological correction of autistic disorders and the formation of the readiness of children with autism spectrum disorders to study at school, however, the issues of the formation of cognitive readiness for school children with autism spectrum disorders of senior preschool age in the pedagogical aspect have not been sufficiently covered [6].

The effectiveness of the application of applied behavior analysis (ABA therapy) was investigated $[7,8]$, however, the issues of organizing the use of ABA therapy at home by parents raising children with autism spectrum disorders of senior preschool age are not covered. The features of the TEACCH program for children with autism spectrum disorders were considered [9], which did not determine the stages of using the TEACCH program for senior preschool children with autism spectrum disorders. Scientists [10] determined the effectiveness of using the alternative communication system PECS, but did not indicate the peculiarities of using PECS computer applications for children with autism spectrum disorders and intellectual disabilities. A systematic review of sensory integration therapy was undertaken [11], which did not consider the use of aggravated vests in the teaching and education of children with autism spectrum disorders in senior preschool age. The study of the readiness of a child with autism spectrum disorders to study at school was carried out [12], but methods of determining the level of cognitive readiness for educational activity of children with autism spectrum disorders of senior preschool age were not investigated.

The problem of cognitive readiness for educational activity of children with autism spectrum disorders remains relevant and is determined by many factors, the main one of which is "low 
level of functional readiness" ("school immaturity"), i. e. inconsistency of the degree of maturation of certain brain structures, neuropsychic functions with the task of school education. Taking into account the peculiarities of the psychophysical development of children with autism spectrum disorders of senior preschool age, in order to form cognitive readiness for educational activities, it is advisable to use modern correction technologies.

The aim of research is to substantiate the effectiveness of the use of correctional technologies as a condition for the formation of cognitive readiness for educational activity in children with autism spectrum disorders of senior preschool age.

\section{Materials and methods}

To ensure the reliability of the provisions and conclusions, theoretical methods were used: comparison and systematization of research material to determine the effectiveness of the use of correction technologies in the process of forming cognitive readiness for educational activities in children with autism spectrum disorders; deductive - for a systematic description of the investigated phenomenon; inductive - to establish patterns, systematize the results of empirical research.

\section{Research results}

Readiness to learn at school is an integrative characteristic of a child's mental development, which encompasses components that ensure its successful adaptation to the conditions and requirements of the school. This phenomenon arises as a general (psychological) and special readiness for learning at school, which reveals the levels of development of those psychological qualities that most contribute to the normal entry into school life, the formation of educational activities [13, 14].

Researcher V. Tarasun argues that the functional inadequacy of the educational abilities of a child with autism spectrum disorders is the root cause of difficulties in schooling and, therefore, work to prevent the occurrence of academic failure should begin with the identification and development of those psychophysiological mechanisms that ensure the formation and development of the learning abilities themselves. "The teacher should go from the task of developing in the student general groups of operations, or the so-called general components of mental activity, do not depend on the specific features of the subject" [1].

Taking into account the results of the analysis of scientific literature, the developmental features of children with autism spectrum disorders of senior preschool age, it is possible to state that cognitive readiness is such a readiness that is formed i develops on the basis of the cognitive need in various types of activity, provides the level of development of those psychological qualities that most contribute to normal entry into school life, the formation of educational activity $i$ is characterized by the existing cognitive orientation of the preschooler. The components of cognitive readiness are mental processes: memory, attention, perception, thinking, imagination.

For the effective formation of cognitive readiness for educational activities in children with an early spectrum of autism in senior preschool age, the following rules must be observed:

1) constancy - continuity of learning, depends on adults (teachers and parents of children with autism), on their responsibility, perseverance, will and desire to help the child;

2) sequence - construction from simple to complex in everything: from commands - requests aimed at performing small purposeful movements, indicating complex actions;

3) gradualness, requiring patience and understanding that there are periods of progress and regression in a child's development. In order to clearly know that the child is moving forward in learning, one must see these successes, mark them, write them down, not count on very rapid progress;

4) order as certain patterns regarding the organizational components of the classes: time, place, symbols-markers of the beginning/end of the class, and the like;

5) step by step. The child must be told exactly what he/she has to do; show how to do it; perform together the action that he/she is taught, do it with the child. Step by step also means that every action, skill that needs to be taught, is also broken down into steps;

6) encouragement, which can be a smile, hugs, stroking the back, verbal praise, a treat, favorite activities. In this case, the child should experience not demonstrative, but sincere feelings of the teacher. 
It is proven worldwide that ABA therapy technologies, TEACCH program, (PRT), PECS, sensory integration contribute to the effective teaching and upbringing of children with autism spectrum disorders. Let's consider the effectiveness of the use of correctional technologies as one of the conditions for the formation of cognitive readiness for educational activities in children with autism spectrum disorders.

Applied Behavior Analysis (ABA-therapy) improves communication skills and achieves learning behavior. At the same time, the manifestations of behavioral deviations are significantly reduced. The earlier a therapeutic course begins (preschool age), the better its results. ABA-therapy methods contribute to the formation of cognitive readiness for educational activity in children with autism spectrum disorders of senior preschool age in the following areas:

- formation of skills that replace problem behavior. Desirable behavior increases and unwanted behavior decreases;

- increasing the ability to focus on completing tasks and increasing motivation to learn;

- increasing concentration of attention, eye contact;

- improving cognitive skills;

- non-verbal and verbal imitation;

- development of general and fine motor skills;

- understanding of speech;

- naming of objects and actions;

- ability to classify objects (decomposition of cards with a dog and a cat in one pile, and cards with a spoon and fork in another, look for a pair; symbolic actions, such as: "show how you are ..." (the child pretends that puts on a hat/combs hair/extinguishes the fire/turns the steering wheel, etc.); correctly use the pronouns "I am standing" - "you are standing", etc.).

The main task of ABA is the maximum possible social adaptation of children with autism spectrum disorders, which is achieved by teaching as many individual skills as possible using the methods of operant conditioning (reaction - stimulus - reinforcement). The focus is on the external appearance rather than the internal characteristics of senior preschool children with autism spectrum disorders.

TEASSN program provides a broad corrective approach that includes careful individual assessment of the strengths of children with autism spectrum disorder. TEACCH proposes, given the tendency of children with autism spectrum disorders to become routine, always place prepared tasks in the same sequence: more often from left to right: there are always unfulfilled tasks on the left, and completed ones on the right. It is recommended to select the number of tasks to be performed so that they can be completed in one step. Thus, by the number of unfulfilled tasks the child can understand how much remains to be done. When all the tasks are on the right, the lesson ends. An senior preschool child with autism spectrum disorders can determine what to do next by their daily routine. This approach can be used for any kind of activity. TEASSN program promotes:

- development of maximum independence. The development of individual lesson programs is carried out with an emphasis on the independent activity of the student (for this, the system of visual "prompts" is used), and the tasks themselves are selected taking into account the level of the child's development;

- establishing effective contact with other people. Much attention in TEACCH programs is paid to the development of communication skills (communication, games) of a socially acceptable level. Children are in contact not only directly with the teacher, but also among themselves, for which special group tasks have been developed;

- development of intelligence, school skills and individual talents of the child. Within the TEACCH-program, there are tasks for the formation of the ability to read, write, count, navigate in time and space, etc.

TEASSN approach focuses on intrinsic factors and the individual characteristics of each individual child with autism spectrum disorders in senior preschool age. TEASSN method is based on fundamental theoretical and empirical research devoted to the problem of autism, its manifestations, characteristics, causes of occurrence and possible result.

Pivotal Respouse Treatment (PRT) - preparation of basic/key skills/reactions aimed at developing motivation for learning, social initiative, the ability to respond to multiple signals, self-manage- 
ment. This further facilitates the perception of educational information. The main goal of PRT is to develop the motivation of a child with autism spectrum disorder to respond to cues and social interactions that can replace inappropriate or atypical behavior. PRT differs from other methods because the focus is on improving developmental deficits rather than focusing on specific behaviors.

PECS (Picture Exchange Communication System) alternative communication system allows children with autism spectrum disorders to communicate with other people, namely, to convey their request, answer questions, make comments, describe the environment, and the like. PECS is alternative communication systems aimed at helping children with limited communication skills acquire communication skills. In this system, children for communicative purposes use the symbols depicted on the cards. Mastering the PECS system involves teaching a child with autism spectrum disorder to use a symbol (picture on a card with the appropriate caption) to ask for a desired item. The PECS Alternative Communication System improves:

- eye contact;

- concentration of attention;

- flexibility of thinking;

- strength of memorizing the names of objects;

- readiness to receive information;

- ability to communicate.

The concept of "sensory integration" reproduces the result of the process of receiving signals from the internal and external environment to the brain. The immediate task of this training system is to teach the brain to respond correctly to external stimuli. At the same time, equipment of different types is used: swings, platforms for training balance, large balls and rollers, skateboards, and the like.

Sensory games, train visual perception, develop observation, attention, memory, form an idea of color, shape, size, spatial arrangement of objects, increase the vocabulary of children with autism spectrum disorders of senior preschool age. The development of visual and auditory perception, understanding of addressed speech is carried out in the process of cognition by a child with autism spectrum disorders of objects and phenomena of the surrounding reality, that is, the development of speech and the development of cognitive processes are carried out simultaneously. Sensory integration helps to develop such skills and psychological education as the ability to concentrate, organize impressions, abstract reasoning, self-control, that is, everything that can function normally in everyday life, in childhood, family, and over time in adult life. Thus, the sensory integration techniques used in correctional work help to meet the needs of a child with autism spectrum disorders in awareness of themselves, the surrounding objective world, provide the development of motor, speech, communicative, cognitive, sensory skills.

\section{Discussion}

The results of studies by many scientists show that the mental, emotional and social development of children with autism spectrum disorders depends on a positive attitude towards them, understanding and acceptance of their needs by teachers, parents and other children. Therefore, correctional and educational work should be systematic, and the primary task of an adult is to create an atmosphere of trust, encourage a child to communicate, and activate non-verbal communication methods. For the formation of cognitive readiness for educational activity in children with an early spectrum of autism in senior preschool age, it is necessary to use ABA therapy technologies, the TEACCH program, (PRT), PECS, sensory integration, which improve the formation of components of cognitive readiness: memory, attention, perception, thinking, imagination. A child with autism spectrum disorders needs systemic assistance, extended over time, and when planning educational activities, it is necessary to take into account the age, gender, developmental characteristics of an senior preschool child with autism spectrum disorders and the recommendations of specialists. It is important to remember that all educational material for a child with autism spectrum disorders should be supported by visual evidence (TEACCH, PECS), which reflects a clear algorithm of actions, as well as the implementation of practical tasks. So, visual tools provide information, have a positive effect on the memorization process, contribute to the organization of thinking, the development of communication skills. The method (ABA-therapy) improves the 
stability of concentration, forms learning behavior, and the method (PRT) contributes to the development of child's motivation and self-management. The formation of imagination and perception of the surrounding world is carried out in the process of conducting classes with sensory integration. Thus, the use of ABA therapy technology, the TEACCH program, (PRT), PECS, sensory integration, is one of the main conditions for the formation of cognitive readiness for educational activity in children with autism spectrum disorders in senior preschool age.

\section{Conclusions}

According to the results of an empirical study, it is revealed that the use of correction technologies is one of the conditions for the formation of cognitive readiness for educational activities in children with autism spectrum disorders of senior preschool age. It has been proven that ABA-therapy technologies, TEACCH, (PRT), PECS, sensory integration programs affect the formation of components of cognitive readiness: memory, imagination, perception, thinking, attention of children with autism spectrum disorders in senior preschool age. We see the prospect of further research in examining the level of cognitive readiness for learning activity in children with autism spectrum disorder and the formation of components of cognitive readiness, which is a prerequisite for learning activity in children with autism spectrum disorders in senior preschool age.

\section{References}

[1] Tarasun, V. V. (2018). Autolohiia i praktyka. Kyiv: Vadeks, 590.

[2] Ostrovska, K. O., Kachmaryk, Kh. V. (2013). Osoblyvosti psykholohichnoho suprovodu navchannia autychnykh ditei. Naukovyi chasopys NPU im. M. Drahomanova. Seriia 19. Korektsiina pedahohika ta psykholohiia, 23, 370-374.

[3] Rybchenko, L. K. (2016). Psykholohichni mekhanizmy stvorennia pedahohichnykh umov efektyvnoi korektsiinoi roboty z autychnymy ditmy. Naukovyi chasopys NPU imeni M. P. Drahomanova. Seriia 19. Korektsiina pedahohika ta spetsialna psykholohiia, 32 (2), 83-90.

[4] Skrypnyk, T. V. (2019). Pidhotovka dytyny z rozladamy autystychnoho spektra do navchannia u zakladi osvity. Kyiv: Aliant, 84.

[5] Chuprykov, A. P., Khvorova, H. M. (2012). Rozlady spektra autyzmu: medychna ta psykholoho-pedahohichna dopomoha. Lviv: Ms, 184.

[6] Shulzhenko, D. I. (2010). Autyzm - ne vyrok. Lviv: Kalvariia, 224.

[7] Cooper, J. F., Heron, T. E., Heward, W. L. (2014). Applied Behavior Analysis, 143-205

[8] Smith, T., Klorman, R., Mruzek, D. W. (2015). Predicting Outcome of Community-Based Early Intensive Behavioral Intervention for Children with Autism. Journal of Abnormal Child Psychology, 43 (7), 1271-1282. doi: http://doi.org/10.1007/ s10802-015-0002-2

[9] Virues-Ortega, J., Julio, F. M., Pastor-Barriuso, R. (2013). The TEACCH program for children and adults with autism: A meta-analysis of intervention studies. Clinical Psychology Review, 33 (8), 940-953. doi: http://doi.org/10.1016/j.cpr.2013.07.005

[10] Ganz, J. B., Hong, E. R., Goodwyn, F. D. (2013). Effectiveness of the PECS Phase III app and choice between the app and traditional PECS among preschoolers with ASD. Research in Autism Spectrum Disorders, 7 (8), 973-983. doi: http:// doi.org/10.1016/j.rasd.2013.04.003

[11] Lang, R., O’Reilly, M., Healy, O., Rispoli, M., Lydon, H., Streusand, W. et. al. (2012). Sensory integration therapy for autism spectrum disorders: A systematic review. Research in Autism Spectrum Disorders, 6 (3), 1004-1018. doi: http:// doi.org/10.1016/j.rasd.2012.01.006

[12] Pellicano, E., Kenny, L., Brede, J., Klaric, E., Lichwa, H., McMillin, R. (2017). Executive function predicts school readiness in autistic and typical preschool children. Cognitive Development, 43, 1-13. doi: http://doi.org/10.1016/j.cogdev.2017.02.003

[13] Novak, O. M. (2013). Hotovnist dytyny do navchannia u shkoli yak osnova zabezpechennia nastupnosti navchannia v doshkilnykh navchalnykh zakladakh ta pochatkovii shkoli. Visnyk Natsionalnoi akademii Derzhavnoi prykordonnoi sluzhby Ukrainy, 1, 16-25.

[14] Pochkun, Yu. O. (2016). Vyvchennia dosvidu zastosuvannia novitnikh korektsiinykh tekhnolohii u roboti z autychnymy ditmy. Chastyna 2. Kyiv: NPU imeni M. P. Drahomanova, 32, 78-83. 